\title{
Constitutional and Legal Development of the Freedom of Public Meetings in Jordan
}

\author{
Mohammed Ali Al-Shabatat ${ }^{{ }^{*}} \quad$ Murad Tayseer Al-Shawawreh $^{2}$ \\ 1.Associate Professor of Constitutional and Administrative Law, Faculty of Law / Middle East University, \\ Jordan \\ 2. Legal Researcher, Jordanian Customs, Amman, Jordan
}

\begin{abstract}
:
Freedom of meetings, like other public freedoms, requires a democratic climate and an advanced cultural and economic level in order to achieve the desired results and prevent the public authorities from attacking them. Based on the awareness of the Jordanian State of the importance of freedom of meetings in achieving democratic rule, and communicating the opinions and demands of citizens to the public authorities in the State. In Jordan's successive constitutions, it ensured the assertion of this freedom as a Constitutional right guaranteed to Jordanians. It also referred the organization of its exercise to its regular laws. In response to that, the Jordanian legislator issued a number of successive public meeting laws that imposed restrictions on freedom of meetings on the one hand, and clarified the procedures for exercising and organizing them, on the other hand.
\end{abstract}

Keywords: Constitution, laws, public meetings, freedom, Constitutional development

DOI: $10.7176 / \mathrm{JLPG} / 100-03$

Publication date:August $31^{\text {st }} 2020$

\section{Introduction:}

The Hashemite Kingdom of Jordan is one of the first countries in the Arab region, and indeed one of the first developing countries that has taken care of human rights, as it has enshrined through its successive Constitutions a democratic approach that places value on man, and affirms an early and deep understanding of public freedoms and the rights of the Jordanian citizen. The right to assembly was one of the rights affirmed by Jordanian Constitutions from the beginning of the emirate regime to the present day. Given that the provisions of the Constitution do not expand to regulate every right or freedom of liberties, rather it merely establishes the legal principle and then leaves the ordinary laws to put in place the appropriate mechanism to regulate the practice of this right or enjoy that freedom, therefore, the Jordanian legislator issued a number of laws regulating the freedom of public meetings, which came in response to Constitutional principles, and a translation of the political philosophy adopted by the Jordanian State.

The study of the Constitutional and legal development of freedom of public meetings in Jordan requires studying the Constitutional development of freedom of public meetings in successive Jordanian Constitutions, in Chapter One. Then, we will show the legal development of freedom of public meetings in successive Jordanian Constitutions and laws, in Chapter Two.

\section{Research problems:}

The problem of the study revolves around finding a clear, specific and balanced standard that clarifies the right to exercise public rights and freedoms and affirms this freedom as a right guaranteed by successive Jordanian Constitutions, without imposing any restrictions on this freedom that would limit the exercise thereof.

\section{Research questions:}

This research seeks to answer the following questions:

1. How did the Jordanian Public Meetings Law address the freedom of public meetings, and how consistent is this law with the Constitution in ensuring freedom of assembly?

2. What are the stages of Constitutional development that the freedom of public meetings in Jordan went through?

3. What aspects can be strengthened in the Jordanian Public Meetings Law to enhance freedom of public assembly in Jordan?

\section{Research importance:}

The importance of the research is represented in the following:

1. Highlighting the development of the freedom of public meetings in successive Jordanian Constitutions on the one hand, and the laws of public meetings regulating that freedom, on the other hand.

2. The importance of the research is also evident in notifying the administration's authority of the necessity of its adherence to the Constitution, as it is a social document between the State and its citizens, especially with regard to public freedoms and rights, as well as adherence to the rules and legal procedures for organizing and 
exercising the freedom of public meetings in Jordan.

\section{Research objectives:}

The objectives of this research are represented in the following:

1. Explaining the shortcomings or deficiencies in the Jordanian Public Meetings Law through the analytical study of its Articles, and the extent to which it fulfills the Constitutional and legal guarantees of the right of assembly.

2. Establishing appropriate solutions and provisions for the accurate equation in the field of reconciliation between the necessity of implementing the Constitutional provisions related to guarantees of freedom of public meetings on the one hand, and administrative control authorities in maintaining public order, on the other hand

\section{Research methodology:}

In this study, both researchers will rely on the descriptive analytical approach, whereby the researcher will review the provisions of the Jordanian Constitution and the Jordanian Public Meetings Law, as well as present, analyze and interpret the provisions related to the freedom of public meetings.

\section{Chapter One: \\ Constitutional development of the freedom of public meetings in successive Jordanian Constitutions}

The Constitution in every country clarifies the idea of the group and its conception of the common future, the political philosophy adopted by the State, and the principles upon which this State is based, for which laws and legislation must be executed to achieve them. Therefore, the provisions of the Constitution are the highest rules, which transcend other legal rules, and which shall not be violated or challenged by the rulers or the ruled, hence the words of the French constitutional jurist, Georges Burdeau, say: "The Constitution is indispensable in order to provide the State with a stable pillar without which government action will be at the mercy of the whims of the passing rulers", ${ }^{1}$ and this is confirmed by some: "Constitutions determine the formal idea of law in the State, when they determine the general political, social and economic trends in which all aspects of individual and governmental activity alike must depend on, that is, Constitutions are considered the general legal framework for the entire life of the State, thus they inevitably oblige rulers to adhere to them when choosing between the goals and directions that their activity should seek when they oversee the functioning of public services, and when they direct the life of the group and the relationships of individuals. It is not correct to understand from this that the Constitution inevitably eliminates attitudes and philosophies that contradict its point of view, rather it allows for them, to varying degrees according to the different political systems, to take their place in the opposition."2

Thus, we find that the successive Constitutions issued in Jordan emphasized the freedom of individuals to have public meetings, and referred to the law the method of practicing this freedom, but we mention here that although the right to freedom of public assembly is a constitutional right, this does not mean in any way that it is an unlimited right. It is not, like other civil and political rights, unlimited in the national Constitutions that permitted the imposition of organizational restrictions on its practice, provided that they do not empty it of its content, and provided that these restrictions are necessary to protect the democratic society and commensurate with the goal to be achieved in maintaining security and public order and protecting the rights and freedoms of individuals ${ }^{3}$.

The researcher will study the Constitutional development of freedom of assembly in successive Jordanian Constitutions through three topics:

First Topic: Freedom of assembly according to Organic Law (Constitution) of 1928 in Emirate of Transjordan.

Second Topic: Freedom of assembly according to the Jordanian Constitution of 1946. Third Topic: Freedom of assembly according to the Constitution of the Hashemite Kingdom of Jordan in 1952 and its amendments.

\section{First Topic:}

Freedom of assembly according to Organic Law (Constitution) of 1928 in Emirate of Transjordan The Organic Law of 1928 in Emirate of Transjordan was issued as a doctoral grant by Emir's sole will. This organic law is distinguished as a written constitution issued on April 16, 1928. It contained seventy-two articles includes an introduction and seven chapters, the first chapter discusses the rights of the people, The Organic Law affirmed a set of rights and freedoms that Jordanians should enjoy, including the right of Jordanians to assemble,

(')BURDEAU. (G): L'Etat, éditions du Seuil, Paris, 1970, p.75.

Referred to by Arnous, Ghassan Selim, (2012). The Principle of the Correlation Between Power and Responsibility in Contemporary Political Systems Between Theory and Practice, PhD thesis, Faculty of Law, University of Damascus, p. 115.

${ }^{2}$ Al-Jarf, Taima, (1966). Theory of State and the General Basis of Political Systems, Book Two, First Page, Modern Cairo Library, p. 99.

${ }^{3}$ Nasrawin, Laith. Study on the Jordanian Public Meetings Law No. (7) of 2004 and its Amendments, Amnesty International, Regional Office for the Middle East and North Africa - p. 218 
in its eleventh article, which states: " All Jordanians are free to express and publish their opinions, to hold meetings together, to form associations and to be members of them in accordance with the provisions of the law ${ }^{(1)}$ " It is clear that the old Organic Law (constitution) only stipulated the right to assembly, and referred its restrictions, the way to be organized and practiced to the law.

Although the Organic Law includes a set of rights and freedoms for the people such as the freedom of assembly, the actual and practical application of these rights remained deficient due to the lack of legal guarantees that ensure people the enjoyment of these rights and freedoms ${ }^{(2)}$, Jordan was subject to the British Mandate. In addition, the cultural and economic level and the political awareness available to the Jordanian people at that era, did not allow an appropriate environment to apply those rights and freedoms.

\section{Second Topic:}

Freedom of meetings according to the Jordanian Constitution of 1946.

The Legislative Council ratified the Constitution of the Hashemite Kingdom of Jordan on 28th November 1946. It was issued by the king and predecessor Abdullah I Bin Al Hussein on 7th December 1946 and published in the Official Gazette on 1st February 1947. The constitution of 1946 was distinguished as a writing constitution which some people think that it was enacted through contracting. It includes 79 articles that form an introduction and eight chapters. The first chapter discusses the rights of the people, as it stipulates that personal freedom is guaranteed, affirms the inviolability of residences and the protection of private property, and ensures freedom of opinion and expression. The Article eighteen thereof states, the Jordanians have the right to hold meetings, confirming the aforementioned Article of the Organic Law of 1928, as it states that: "Jordanians shall have the right to hold meetings and establish associations within the limits of the law" (3), Most Arab constitutions at that era adopted the same approach adopted by the Jordanian constitution, which was issued at an era when Arab countries began to liberate from the yoke of colonialism, and look forward to a future in which freedom for their peoples would be achieved.

\section{Third Topic:}

Freedom of meeting according to the Constitution of the Hashemite Kingdom of Jordan in 1952 and its amendments.

The current constitution of the Hashemite Kingdom of Jordan was issued after its approval by the Senate and the House of Representatives, and was submitted to King Talal bin Abdullah, who ratified and promulgated it on 1st January 1952, and was applied since the date of its publication in issue No. 1093 of the Official Gazette on 8th January 1952.

The Jordanian constitution dedicates the Second Chapter thereof, to determine the rights and duties of Jordanians, and many of these rights and freedoms were inspired by the Universal Declaration of Human Rights issued by the United Nations General Assembly on 10/12/1948.

Where the Jordanian constitution decides in its article 5 that Jordanian nationality shall be defined by law, then it acknowledges the principle of equality among Jordanians, and article 6 thereof, stipulates the duty of every Jordanian to defend the country, and obligated the state to ensure work and education, and the constitution stipulated that personal freedom is inviolable and protected the freedom of opinion and the freedom to perform Religious rites and beliefs, in addition it stipulates that it is not permissible to prevent Jordanians from residing in a certain place or prevent them from moving, and decided to inviolability of residences and the protection of private property .... Furthermore, it stipulates freedom of meeting in the first clause of Article 16 thereof. Which he states: " Jordanians shall have the right to hold meetings within the limits of the law." $\left({ }^{4}\right)$, In 2011 , the constitutional legislator added an essential amendment presented in the first clause of Article 128, which states that: The laws issued in accordance with this Constitution for the regulation of rights and freedoms may not influence the essence of such rights or affect their fundamentals. $\left(^{5}\right)$

The importance of this amendment lies in preventing the legislative authority from violating the rights and freedoms established by the constitution for Jordanian citizens on the pretext of organizing them. If a law violates these rights or confiscates these freedoms, then it is considered as an unconstitutional law, the Constitutional Court, which was created by the constitutional amendments in 2011, can null it, and that represents a great protection and a sure guarantee of public rights and freedoms, including freedom of meeting.

Therefore, we find that successive constitutions in the Hashemite Kingdom of Jordan have been devoted to ensure that Jordanian citizens enjoy all civil rights and public freedoms, including freedom of meeting, in order to ensure that the value of these rights and freedoms are upheld, and to ensure respect for laws and state authorities.

$\left({ }^{1}\right)$ http//: www.lawjo.net/.../showthread.php?...1928.

( ${ }^{2}$ Al-Khatib, Noman, 2014, The Al-Baseet in the Constitutional System, 1st Ed., Dar Al Thaqafa, Amman, Jordan, p. 52.

$\left({ }^{3}\right)$ http//: www.lawjo.net/.../showthread.php?...1946.

(4) http//: www.lawjo.net/.../showthread.php?...1952.

$\left({ }^{5}\right)$ http//: www.lawjo.net/.../showthread.php?...1952. 


\section{The second Chapter:}

Legal development of the freedom of public meetings in successive Jordanian meetings law.

Freedom of assembly finds its natural place into the constitutions, which is the approach adopted by various countries, but legal and practical considerations prevent the provisions of the constitution from expanding to the details of exercising that freedom. That is why the constitutions delegate this task to the law; the stipulation of freedom of assembly into the constitution does not mean exempting it from any restriction or regulation; rather, it remains relative freedom and within the limits of the law, that the use of freedoms and the practice of various types of activity takes many ways and directions and aims to achieve various purposes. Due to the nature of things, they must be organized. Otherwise, the lack of their organization led to them turning into a chaos that is not related to freedom, and is nothing more than a physical act that has no legal status ${ }^{(1)}$. Therefore, the legislator had to intervene to organize freedom in order to reconcile multiple considerations, such as reconciling the freedom of the group and the freedom of the individual or reconciling freedom and responsibility. Accordingly, the legal organization of freedom is the only way to practice it, as this practice is the basic principle and not exercising it is an exception to that principle. By this, we realize how the law is a necessary restriction on freedom, and a fundamental guarantor of its exercise. In that regard, the French constitutional jurist Esmein states: "If the legislator does not regulate the public freedoms, then the right guaranteed by the constitution to the individual cannot be used and remains a mere promise that does not confer rights on a specific legal right" (2).

It has been found through our research of the constitutional development of assembly freedom under successive constitutions of Jordan that the provisions of the constitution have always been restricted on emphasizing freedom of assembly, and allocate to the law the method of how to organize it, so that individuals can apply this the given law as well as the authority is able to impose appropriate restrictions on it. In consequence, it does not turn into chaos that cause disturbance to public order or public decency. On that basis, a number of laws regulating the freedom of public meetings were issued in Jordan: firstly was the temporary Public Meetings Law of 1933 and lately was the Jordanian Law of Meetings No. (5) of 2011 amending the Law of 2004 and the Law of $2008\left(^{3}\right)$. In the following, the researcher will highlight on the freedom of public meetings under these laws.

\section{First Topic:}

Freedom of public meetings under the temporary Public Meetings Law of $1933^{(4)}$

This law was issued during the period in which Jordan was subject to the British Mandate as when the Basic Law of the Emirate of Transjordan in 1928 was the country's constitution. As previously noted, it stipulated the Jordanians right of meeting in accordance with the provisions of the law. This law came in response to the constitutional provision that clarified the need for a law that regulates freedom of assembly. This law derive its provisions from the Egyptian Law on Public Meetings and Demonstrations on Public Roads No. 14 of 1923 , amended by Decree Law No. 28 of 1929, which in turn had derived its provisions from the French Public Meetings and Demonstrations Law of 1881, but it intended to transmit the most arbitrary and strict provisions. $\left({ }^{5}\right)$

This Law has defined the public meeting as each meeting that discuss public matters. Obviously, the Public Meetings Law has expanded the concept of public meeting to include any meeting that takes place whether on a social, religious or economic event. This definition appears to have been in consistent with the definition contained in the Egyptian Law on Public Meetings and Demonstrations on Public Roads No. 14 of 1923- amended by Decree Law No. 28 of 1929- that defined the public meeting in accordance with Article no. 8: "it is every meeting in a public or private place that people with no one-to-one invitation entered or can enter" $\left({ }^{6}\right)$.

The Jordanian Public Meetings Law contained a set of conditions that shall be met to allow the public meeting to be held. As it stipulated that the party interested in holding the public meeting shall submit a prior request to obtain approval to hold the meeting; if no prior approval has been obtained, the meeting may not be held. This is compounded by the need to obtain a series of approvals before the public meeting is held, as holding the public meeting required the approval of the Executive Council (The Cabinet). The latter decides approval or rejection, based on the decision of the Military Region Commander or the Arab Military Chief, who were British at that time because Jordan was under the British Mandate. The rejection of the request to hold the public meeting did not need to provide justifications. In the event of approval, the Executive Council would have dictated the conditions by which the public meeting can be held; what makes matters worse is the presence of the public meeting by the representative of the Military Chief or the representative of the Region Commander $\left({ }^{7}\right)$.

$\left({ }^{9}\right)$ Georges Vedel - Droitconstitutionnel - edition RecueilSiry - Paris - 1949 p: 177

$\left({ }^{(10}\right)$ Esmein - elements de droitconstitutionnelFrancais et compare - Huitieme edition - Tome 1 - Recueilsirey - Paris - 1927 - p: 100.

Referred to by Dr. Arnous, Ghassan Selim, The Principle of Correlation between Authority and Responsibility in Modern Political Systems, op. cit, p. 75

( $\left.{ }^{3}\right) \mathrm{http} / /$ : www.qistas.com/jor/index.php?... Laws...

$\left({ }^{4}\right)$ The Public Meetings Law of 1933, published in the Official Gazette No. 400, on 5/9/1933, p. 334.

$\left({ }^{5}\right)$ Nasrawin, Laith , (2011), Peaceful Assembly in Jordanian Law and International Conventions, Sader Group, Amman, Jordan, p. 258.

$\left({ }^{6}\right)$ http//: www.laweg.net/Default.aspx?....1923.

$\left({ }^{7}\right)$ Article (4) of the Public Meetings Law of 1933, referred to earlier. 
This dystopia has prompted a researcher to say: "... Clearly, these restrictions imposed on holding public meetings derive from the political reality that Jordan was experiencing at that time. The British Mandate was directly interfering in the formulation of policies inside Jordan, as well as interfering in the enactment of laws, the imposition of authority and the dominance of the application of these laws in a manner that serves British interests in Jordan. Some opinions came to consider that the right to freedom of assembly in the Jordanian Public Meetings Law of 1933 was more unfair compared to the era of the Ottoman Empire, despite the fact that its ruling was unjust and coercive, which the Public Meetings Law did not require permission to hold the public meeting. Rather, it was sufficient for the meeting applicant to inform about the place and time of its convening" $\left(^{1}\right)$.

\section{Second Topic:}

Freedom of public meetings under the temporary Public Meetings Law No. (60) of 1953( $\left.{ }^{2}\right)$

After Jordan had its independence, and after the Hashemite Kingdom of Jordan's Constitution of 1952 was issued, which affirmed, as we noted, the right of Jordanians of meeting according to the law, the law that repealed the Public Meetings Law of 1933, and expanded the freedom to hold public meetings in Jordan by defining public meetings more accurately than the previous law was issued. In accordance with this law, the public meeting is any meeting held for the purpose of discussing political matters; Jordanians are entitled to hold public meetings provided that the party interested in holding the public meeting submits a request for that to the alienator 48 hours before the meeting is held. The request consists of signing at least five individuals who will attend the meeting. The request to hold the meeting shall also include the place, date and purpose of the meeting. According to this law, the written notification of holding the public meeting was sufficient to hold the meeting $\left({ }^{3}\right)$, as the party interested in holding the meeting does not wait for the alienator to approve the holding, but rather only reports on the holding of the public meeting. This was an essential and democratic development from a procedural point of view, as the need to obtain prior permission required by the previous law of 1933 have been decommissioned. Hence, this was a step on the path to freedom of assembly in Jordan. On the other hand, the prestige of the authority was taken into account by requiring the presence of a representative of the Military Region Commander and a representative of the alienator.

Many researchers believe that Law No. (60)/1953 came to a great extent in line with the provisions of the Constitution $\left({ }^{4}\right)$, as it reduced the discretion of the administration and limited its ability to abuse its authority. And that is when it was satisfied with just notification to hold the public meeting and abolished the requirement to obtain the prior permission provided for in the 1933 law. It strengthened the democratic approach by giving the Jordanians the right of holding public meetings to discuss political issues, in a period of Jordan's history that required a political churning in order to build a strong and democratic Jordan.

But in order to be objective, we shall mention that the restriction of freedom in accordance with this law was carried out in a different way at this stage. This restriction is embodied in the presence of the Military Region Commander or his representative, and a representative of the alienator, which imposes restrictions on the topics that are addressed during the public meeting. In spite of the existence of this restriction, it has achieved a shift in the field of holding public meetings in Jordan.

\section{Third Topic:}

\section{Freedom of public meetings under the temporary Public Meetings Law No. (45) of 2001(5)}

This law repealed the Public Meetings Law No. (60)/1953, replaced it, and formed a setback on the path to democracy. Instead of decrease the restrictions imposed on the freedom of public meetings, this law returned the country to decades back, and adopted the approach followed by the Public Meetings Law of 1933, which everyone considered a shock to the political life in Jordan, as it reduced the practice of public freedoms, including public meetings. This temporary law represented a repugnant form of restricting public freedoms, specifically the freedom of public meetings. Hence, the procedures applied to allow freedom of assembly were similar to those that were applied under the law of 1933.

This law defined in Article (1) of it the public meeting as a meeting of a public nature, and it was required to submit a request to hold the public meeting or march at least three days before its holding. Article (4) of this law stipulated: "The request to hold the meeting or organize the march shall be submitted at least three days before the date set for any of them" $\left({ }^{6}\right)$. This law has been affected by Egyptian Law No. 14/1923 regarding the period for submitting a request to hold a public meeting, which was specified by the Egyptian Law regarding public meetings

(')Nasrawin, Laith, op. cit, p. 267

$\left({ }^{2}\right)$ The Jordanian Public meetings Law No. (60) of 1953

$\left({ }^{3}\right)$ Article (2) of the Public meetings Law of 1953, Official Gazette No. 1139 of 1/4/1953.

$\left({ }^{4}\right.$ Al Araj, Mousa, The Right of Meeting Between Law 1953 and Law 2004, article published on the website:

http//: www.alrai.com/article m/29653.html.

$\left({ }^{5}\right)$ The Jordanian Public meetings Law No. (45) of 2001, Official Gazette No. 4503 of 28/8/2001.

$\left({ }^{6}\right)$ Article (5)of the Jordanian Public Meetings Law No. (45) of 2001. 
and demonstrations on public roads at least three days before a public meeting or march. However, Egyptian Law has differed from Jordanian Law by limiting the time for submitting the request to twenty-four hours only if the meeting is electoral, while Jordanian Law did not differentiate between electoral meetings and other public meetings for the purpose of submitting a request to hold the public meeting $\left({ }^{1}\right)$. The aforementioned law gives the authority to accept or reject the public meeting or march of the administrative governor twenty-four hours before the public meeting or $\operatorname{march}\left({ }^{2}\right)$. This gives authority to the administrative governor to decide the possibility of holding or rejecting the public meeting, and that is a return to the absolute discretionary authority that the administration enjoys and through which it can be abusive and tyrannize without supervision or accountability. This restricts the freedom to hold public meetings held to discuss issues of public interest. Further, this law stipulated the submitting a list of the names of the meeting applicants, their addresses and their place of residence, as well as specifying the purpose, place and time of the meeting or the march. Article (4) clause (b) stipulates, "The request shall include the names of the applicants, their addresses and their signatures, the purpose of the meeting or the march, and the place and time of either of them" $\left({ }^{3}\right)$. Approval of the meeting may be withheld without mentioning the reasons.

In the absence of consent, applicants are not entitled to meet, and if the public meeting or a March is approved, the law gives the administrative governor the power to take the necessary measures during the meeting or the march to maintain security and public order, protect public and private properties, and charge the associated authorities or the security forces to do this task ${ }^{(4)}$, Article (7) of the law in 2001, stipulated that the administrative governor has the right to issue orders to the security forces to break up the meeting or march in the event that it violates public sovereignty or public property or deviates from its subject explained in the application.

The conditions set forth in the Public Meetings Act 2001 restrict the freedom holding public meetings, and also make the Governor an absolute authority without any control and which can destroy the freedom of holding public meetings in Jordan according to the provisions of the law which provides the appropriate reasoning for their arbitrariness and tyranny. The law also shows that the subjects raised in public meetings are restricted, as the organizers of the meeting have to disclose the subject of the meeting and the points to be discussed during the meeting. Consequently, exceeding the defined subjects of public meeting, is a violation of the law and deserves penalty. Furthermore, the powers of the administrative governor which authorizes him to break the meeting up by force. The Act gives the administrative governor all the powers to approve public meetings, accept or reject their subjects. This procedure restricts the freedom of opinion and expression for organizing public meetings, and represents a serious violation of the rights stated in the Constitution which affirmed the freedom of opinion and expression, and freedom to hold public meetings.

\section{Fourth Topic}

Freedom of public meetings under the temporary Public Meetings Law No. 7/2004 and its amendments ${ }^{(5)}$. As a result of the severe criticism of the 2001 Interim Public meetings Law and popular demands for repealing it, the Public meetings Law No. 7/2004, article (1) thereof, defined the public meeting as the meeting held to examine a matter of public policy ${ }^{(6)}$. In this Law, the restriction of public meetings was limited to those meetings which discuss subjects of a political nature and related to the State, whereas in the aforementioned law public meetings were viewed as belonging to all subjects of a general nature, and the aforementioned law did not exclude social and economic topics from obtaining prior permission to organize them.

An explicit provision is stipulated in Law No. 7/2004 excluding a wide range of public meetings, most of which discuss particular subjects far from politics, from obtaining a prior permission for the meeting. The law exempts meetings related to the objectives achievement of public bodies of charitable associations, voluntary corporations, companies and business chambers, and stipulates that such meetings shall be restricted to legislations in force within those organization ${ }^{(7)}$. Professional meetings held in trade unions ${ }^{(8)}$, meetings of political parties held within parties that adhere to the political parties law are in force ${ }^{(9)}$, seminars and information programs of official Broadcasting institutions ${ }^{(10)}$, meetings within university campus ${ }^{(11)}$, meetings for national and religious events $^{(12)}$ and meetings held during general elections, were also excluded. ${ }^{(13)}$ The law required that the Ministry

( $\left.{ }^{1}\right)$ Nasrawin, Leith, op., p. 270

$\left({ }^{2}\right)$ Article (5) of the Jordanian meetings Act 2001

(3) Article 4, section B, of the Jordanian Public meetings Act 2001

(4) Article 6, of the Jordanian Public meetings Law 2001

$\left(^{5}\right)$ of the Jordanian Public meetings Act No. 7 of 2004, Official Gazette No. 4653 of 15/4/2004, published on the website:

$\left({ }^{6}\right.$ Article(1) of the Jordanian Public meetings Act No. 7 of 2004, Official Gazette No. 4653 of 15/4/2004.

( ${ }^{7}$ ) Article 3, paragraph (a), Section (1), of the Public meetings Act of one year 2004

$\left({ }^{8}\right)$ Article 3, paragraph (a), Section (2), of the Public meetings Act of one year 2004

( $)$ Article 3, paragraph (a), Section (3), of the Public meetings Act of one year 2004

$\left({ }^{10}\right)$ Article 3, paragraph (a), Section (4), of the Public meetings Act of one year 2004

$\left({ }^{11}\right)$ Article 3, paragraph (a), Section (5), of the Public meetings Act of one year 2004

${ }^{12}$ ) Article 3, paragraph (a), Section (6), of the Public meetings Act of one year 2004

$\left({ }^{13}\right.$ ) Article 3, paragraph (a), Section (7), of the Public meetings Act of one year 2004 
of Interior shall be informed of the desire to hold such meetings a week in advance, although the Public meetings were free to be held, the legislator grant the executive authority the power to control these meetings under the conditions stated in Law No. 7/2004.

The Law No. 7/2004 affirmed that a approval request for the holding a general meeting shall be submitted 48 hours in advance, including the names, lists, addresses, purpose, place and time of the meeting $\left({ }^{1}\right)$, In this respect, the conditions for obtaining approval for holding public meetings remained in conformity with those stated in the Law of 2001 which acknowledge that the right to approve holding a general meeting, is by the administrative governor. This Law is distinguished from the previous law by considering that the failure to make any decision to reject the application constitutes a decision to convene the meeting ${ }^{(2)}$, and has also acknowledged the same conditions as those set forth in the 2001 Law concerning the mechanisms for implementing and dissolving public meetings and the right of the governor to control the general meeting. The right to summon security forces to break up the public meeting in the event of deviation from its program ${ }^{(3)}$, or in the event of violating security and public order.

The Public Meetings Law No. 7/2004 did not meet the desired expectations, even did not achieve the reasonable freedom granted to public meetings under the 1953 Law. However, it was distinguished from the 2001 law by restricting the permission to hold meetings in political subjects. It was also distinguished from the previous law by considering that not responding to the request of holding the meeting will be a tacit approval of holding it. These features have not actually made any advance in the freedom of public meetings. This law also continues to enshrine the absolute discretion of the administrative governor to restrict holding and the subjects of public meetings and to select the people holding such meetings. Thus, we can say that this law is an extension of the approach to reducing the freedom of public meetings in Jordan, which some have asserted when they said: ".... Under the provisions of the meetings Law No. 7/2004, the Law goes beyond regulating freedom of meeting to preventing and denying freedoms and assigns the exercise of freedom of meeting to the consent of the administrative governor, who has the right to suppress such freedom on the pretext of maintaining public order, This justification is a broad term whereby decisions to suppress freedom can be justified.... (4)"

As Law 7/2004 has not achieved its intended purpose, the Government has submitted a draft law on the amendment of the Public Meetings Law under the heading of political reform in the context of political development in order to achieve sustainable development. The reasons for amending the Law were to ease restrictions on exercising the freedom of meeting and to provide individuals a better exercise for this freedom, and to exclude certain public meetings from the approval of the Governor. The Public meetings Law No. 40/2008 ${ }^{(5)}$, which is to amend the Public meetings Law No. 7/2004, has unfortunately been amended by the Public meetings Law No. 40/2008, contained formal amendments and does not contain any substantial amendments to the articles and provisions of the aforementioned $\mathrm{Law}^{(6)}$. The Law was amended by adding some provisions on the conditions for holding a general meeting and the powers of the administrative governor to control public meetings. In this amended law, the Governor's approval of the general meeting was required within 24 hours of the application ${ }^{(7)}$. If the request is not rejected during this period, it shall be deemed an implicit approval for the request. Accordingly, the general meeting shall be held in such circumstances and shall not to be considered as a violation of the law.

However, under the amended Law No. 40/2008, the freedom of public meetings gave no additional real ground, but rather formal amendments, and the powers granted to the administrative governor remained to reject, dissolve or terminate any public meeting violates its request, may injure the public or private properties or be detrimental public interest. Thus, this amended law is also considered an extension to the power of executive authority on holding public meetings and giving all powers to the administrative governor in approving public meetings.

The Jordanian Public meetings Law (5)/2011, amending the Law of 2004 and the Law of $2008^{(8)}$, has finally been promulgated. It contains some amendments concerning the formalities of holding public meetings, and requires that a notice of holding public meetings is given at least 48 hours before the date of the general meeting. The Act provided that the names of the organizers of the meeting, together with the request for the meeting, should be seven natural individuals rather than five natural individuals ${ }^{(9)}$, This procedure would help to provide greater guarantees for keeping the public order and security at the time of the General Meeting. Article IV of the Act, section (1), merely provided a notice by the organizers of the General Meeting for the holding of the General

(1) Article 4, section (A,B) of the Jordanian Public meetings Act 2004

${ }^{2}$ ) Article 5, section A, of the Jordanian Public meetings Act 2004

$\left.{ }^{3}\right)$ Articles $(6,7,8)$ of the Jordanian Public meetings Act 2004

$\left({ }^{4}\right)$ Ed Dips, Issam, Public Rights and Freedoms and guarantees of their Protection, Dar Al-Culture, Amman, Jordan, p. 424.

$\left({ }^{5}\right)$ the Jordanian Public meetings Act No. 40 of 2008, Official Gazette No. 4921 of 31/7/2008.

$\left({ }^{6}\right)$ Dipps, Isam, op. cit., p. 424.

$\left({ }^{7}\right)$ Article (5)of the Jordanian Public meetings Act No. 40 of 2008.

$\left.{ }^{8}\right)$ The Jordanian Public meetings Act No. 5 of 2011, Official Gazette No. 5090 of 2/5/2011.

$\left({ }^{9}\right)$ Item (4) Article (2)of the Jordanian Public meetings Act No. 5 of 2011. 
Meeting without waiting for the approval of the Administrative Governor ${ }^{(1)}$. This gave further freedom to hold public meetings in Jordan.

However, more freedom of public meetings was given by Law No. 5/2011, the law assigns the authority to control and dissolve public meetings to the administrative governor, who has broad powers in this area. It also provided for the security services dependence on the administrative governor's decision in dealing with the public meetings.

\section{Conclusion}

The study concluded with defining the constitutional development of the freedom of public meetings in successive Jordanian constitutions and how can the Jordanian legislator organize the exercise of this freedom through successive laws of Jordanian general meetings. The study reached the most important conclusion that the current Jordanian Public Meetings Law No. 7/2004 and its amendments have been distinguished from Jordanian public meeting laws that preceded it, as easing the restrictions on public meetings freedom. It did not require permission or authorization from the administrative governor to convene the general meeting, but only gave the organizers a written notification to the administrative governor 48 hours before the meeting, which is a reasonable time for the administrative governor to take measures to maintain public order and security. In addition, it is undoubtedly as a result of the study that any kind of restrictions that shall be imposed on freedom of meeting shall ultimately aim to make a balance between freedom and public order, so that it does not lead to the tyranny of one over the other. This is in addition to the most important recommendation reached by the study that the Jordanian legislator shall explicitly state the nature of the security measures that shall be taken during the general meeting to maintain order and security without imposing restrictions that may limit the freedom of public meeting.

\section{References :}

\section{First: Arabic references:}

1. Al-Joref, Tuaima, (1964), Theory of State and the General Basis of Political Organization, Cairo.

2. Al-Khatib, Noman, 2014, The Simple in the Constitutional System, First Edition, Dar Al-Thaqafa, Amman, Jordan. 3. Al-Debs, Issam, (2011), Public Rights and Freedoms and Guarantees of their Protection, Dar Al-Thaqafa, Amman, Jordan.

4. Nasrawin, Laith, (2013), Peaceful Assembly in Jordanian Law and International Agreements, Dar Sader Publishers, Amman, Jordan.

5. Nasrawin, Laith, (2012), a study on Jordanian Public Meetings Law No. (7) of 2004 and its amendments, Amnesty International, Regional Office for the Middle East and North Africa.

6. Arnous, Ghassan Salim, (2012), the principle of the correlation between power and responsibility in contemporary political systems between theory and practice, $\mathrm{PhD}$ thesis, Faculty of Law, University of Damascus.

\section{Second: Foreign references:}

1. Georges Vedel - Droitconstitutionnel - edition RecueilSiry - Paris - 1949.

2. Esmein - elements de droitconstitutionnel Francais et compare - Huitieme edition - Tome 1 - Recueilsirey

- Paris - 1927.

3. Burdeau. (G):L'Etat, éditions du Seuil, Paris, 1970 .

\section{Third: Constitutions and Laws:}

1. The Basic Law of the Emirate of Transjordan for the year 1928.

2. The Constitution of the Hashemite Kingdom of Jordan for the year 1946.

3. The Hashemite Kingdom of Jordan Constitution of 1952 and its amendments.

4. Jordanian Public Meetings Law of 1933.

5. Jordanian Public Meetings Law No. (60) of 1953.

6. Jordanian Public Meetings Law No. (45) of 2001.

7. Jordanian Public Meetings Law No. (7) of 2004.

8. Jordanian Public Meetings Law No. (40) of 2008.

9. Jordanian Public Meetings Law No. (5) of 2011.

10. Jordanian Associations Law and its Amendments, No. (51) of 2008.

\section{Fourth: Websites:}

1. http//: www.laweg.net/Default.aspx

2. $\quad \mathrm{http} / /$ : www.lawjo.net/.../showthread.php

3. http//: www.qistas.com/jor/index.php 